\title{
Creep and Mechanical Behavior Study of Inconel 718 Superalloy
}

\author{
Tarcila Sugahara ${ }^{a}$, Antônio Augusto Couto ${ }^{b}$ (1), Miguel Justino Ribeiro Barboza ${ }^{c}$, Francisco Piorino Neto ${ }^{d}$, \\ Renata Jesuina Takahashi ${ }^{a}$ (D), Danieli Aparecida Pereira Reis ${ }^{a *}$ (1) \\ aniversidade Federal de São Paulo, São José dos Campos, SP, Brasil. \\ ${ }^{b}$ Universidade Presbiteriana Mackenzie, Cidade Universitaria, São Paulo, SP, Brasil. \\ 'Universidade de São Paulo, Escola de Engenharia de Lorena, Lorena, SP, Brasil. \\ ${ }^{d}$ Instituto Nacional de Pesquisas Espaciais, São José dos Campos, SP, Brasil.
}

Received: June 11, 2021; Revised: October 21, 2021; Accepted: October 25, 2021

\begin{abstract}
Over the years, the demand for high engine efficiency has resulted in the development of new generation superalloys with improved elevated temperature properties, especially creep resistance. This study aimed to evaluate creep and mechanical behavior of Inconel 718 superalloy. Creep tests were performed at temperature range of 650 to $700{ }^{\circ} \mathrm{C}$ and stress range of 625 to $814 \mathrm{MPa}$. Hot tensile and oxidation tests were performed and the characterization techniques used in this study were scanning electron microscopy (SEM) for microstructural and fracture surface analysis, transmission electron microscopy (TEM) for precipitates analysis; grazing X-ray diffraction for analysis of oxide formation and Vickers microhardness. The analyze of stress exponent value $(n=36.48)$ and activation energy $\left(\mathrm{Q}_{\mathrm{c}}=512.97 \mathrm{~kJ} / \mathrm{mol}\right)$, suggested that creep mechanism at $650^{\circ} \mathrm{C}$ was the climb dislocation mechanism. The Inconel 718 presented ductile fracture at 650 and $700{ }^{\circ} \mathrm{C}$ and intergranular fracture to $675^{\circ} \mathrm{C}$.
\end{abstract}

Keywords: Creep, Inconel 718, Mechanical behavior, Materials characterization.

\section{Introduction}

Nickel-based superalloys are known since the 1930s, and used primarily in aerospace applications ${ }^{1-4}$. These applications require a material with high mechanical strength ${ }^{5,6}$, good resistance to fatigue and $\mathrm{creep}^{7-10}$, good corrosion resistance ${ }^{11}$, and ability to operate continuously at elevated temperatures ${ }^{11,12}$.

Over the last few decades, a few generations of cast superalloy grades with superior elevated temperature properties have been developed ${ }^{3}$. The alloy design principles in these developments are based on maximizing the benefits that could be achieved through increased alloying contents. Because of the high alloy contents, the modern grades of superalloys require stringent control of processing to avoid precipitation of undesirable phases in the microstructure ${ }^{7,13-16}$.

The microstructure of Inconel 718 alloy consists of FCC solid solution austenite $(\gamma)$ in which dispersed precipitate particles can form. It consists of different phases such as gamma prime $\left(\gamma^{\prime}\right)$, gamma double prime $\left(\gamma^{\prime \prime}\right)$, delta $(\delta)$ phase and other phases that occur at high temperature during the aging treatment ${ }^{4}$. The precipitating intermetallic $\gamma^{\text {' }}$ and $\gamma$ " phases promote hardening of Inconel 718 alloy, that the $\gamma$ " phase is the main hardening phase of the alloy acting as a fundamental agent to promoting an increase in the strength of the mechanical alloy $7,917,18$.

Inconel 718 superalloy exhibits excellent mechanical properties and corrosion resistance at elevated temperatures ${ }^{19}$. However, brittle intergranular cracking is observed when

*e-mail: danieli.reis@unifesp.br the alloy is deformed at elevated temperatures ${ }^{5,18,20-23}$. The mechanical properties are influenced by Dynamic Strain Aging (DSA) and the embrittlement effect is related to grain boundary penetration by oxygen. Studies indicate that niobium may segregate to the surface and grain boundaries during heat treatment bringing susceptibility to oxidation ${ }^{24}$. This susceptibility would be attributed to its strong chemical affinity with oxygen?

Creep and creep-fatigue considerations are important in predicting the remaining life and safe inspection intervals as part of maintenance programs for components operating in harsh, high temperature environments. Creep deformation (primary, secondary, tertiary creep) and rupture is one of considerations that are involved in determining the risk of fracture in these structural components that experience harsh environments such as high temperatures and stresses are common in land-based steam and gas turbines, in aircraft engines, and in power-plant components s,8,10,25-29. $^{\text {. }}$

Thereby, the objective of the present study was to investigate Inconel 718 behavior at elevate temperatures.

\section{Materials and Method}

The Inconel 718 superalloy used in this study was obtained by melting furnace VIM, VAR remelting in, homogenization heat treatment, hot forging open die for roughing, roughing hot rolling and hot rolling finishing. The chemical composition of the alloy was $18.80 \mathrm{Fe}, 18.65 \mathrm{Cr}, 3.00 \mathrm{Mo}, 5.10 \mathrm{Nb}, 0.56 \mathrm{Al}$, $1.56 \mathrm{Ti}, 0.03 \mathrm{C}, 0.01 \mathrm{Mn}, 0,05 \mathrm{~S}$ and bal. Ni (in weight \%). 
The Inconel 718 superalloy as received was analyzed under conditions of hot tensile test at temperatures of 600 , $650,700,750,800$ and $850{ }^{\circ} \mathrm{C}$ and strain rate of $0.5 \mathrm{~mm} / \mathrm{min}$ $\left(2 \times 10^{-4} \mathrm{~s}^{-1}\right)$ following ASTM E8/E8M-16ae $1^{30}$ in a machine Instron $4400 \mathrm{R}$ - capacity 10 ton.

The samples of Inconel 718 in circular shape were weighed on a balance to four places of accuracy, before and after the oxidation test. Samples were kept in the oven for 96 hours at temperatures of 600, 650, 675, 700, 750 and $800^{\circ} \mathrm{C}$ and analyzed mass gain. The oxidized samples were subjected to the technique of X-ray diffraction grazing for the evaluation of the oxides formed.

The hardness test was conducted on a FM Futuretech machine model with load $500 \mathrm{gF}$ (five indentations) on the Vickers hardness scale using a microindenter.

Inconel 718 standard samples (as received) and creep tested at $700{ }^{\circ} \mathrm{C}$ and $700 \mathrm{MPa}$ were analyzed by the transmission electron microscopy technique to verify precipitates in the sample. The samples with $3 \mathrm{~mm}$ diameter were sanded until approximately $100 \mathrm{~mm}$ thickness. After polishing were pierced with ionic (PIPs).

The superalloy Inconel 718 was evaluated at temperatures of 650,675 and $700{ }^{\circ} \mathrm{C}$ under stress conditions 625,670 , 700,750 and $814 \mathrm{MPa}$ with constant load. To perform the creep

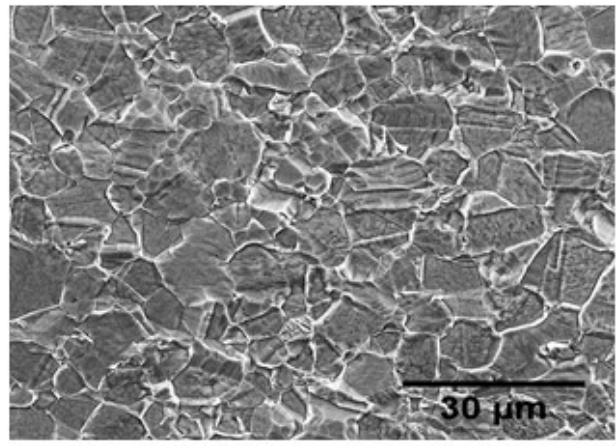

(a) general view tests were used model MAYES furnaces. The creep tests were conducted in accordance with ASTM E139-06 ${ }^{31}$. After the creep test the specimen was prepared by conventional metallographic procedures. Were cleaned in ultrasonic immersed in acetone for 10 minutes, then fracture images were taken for analysis by SEM. The surface fracture images were analyzed in order to relate the test temperature with the fracture mechanism.

\section{Results and Discussion}

\subsection{Inconel 718 superalloy}

In Figure 1 could be seen the microstructure of Inconel 718 superalloy as received, which sample seems to present a small fraction of particles distributed so uniformly by the matrix carbides. The $\gamma$ phase appears lighter in the micrographs in relation to the phase $\gamma^{\prime}$ (in small quantity because there was no aging heat treatment).

\subsection{Hot tensile test}

The specimen was made according to the specifications shown in Figure 2.

All stress-strain curves determined in hot tensile test for Inconel 718 superalloy exhibit typical behavior of metallic

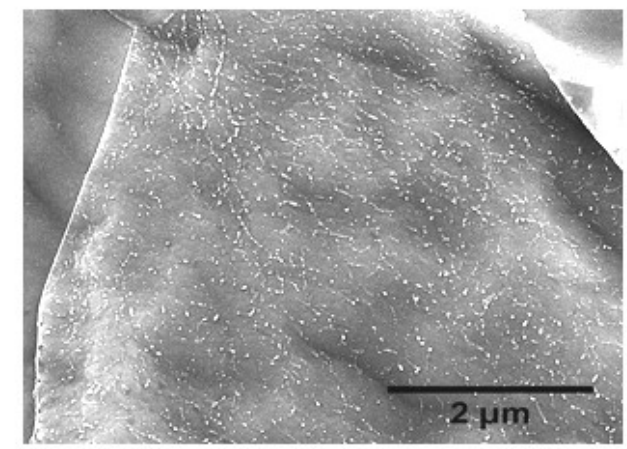

(b) particles in matrix carbides

Figure 1. Microstructure of Inconel 718 superalloy as received.

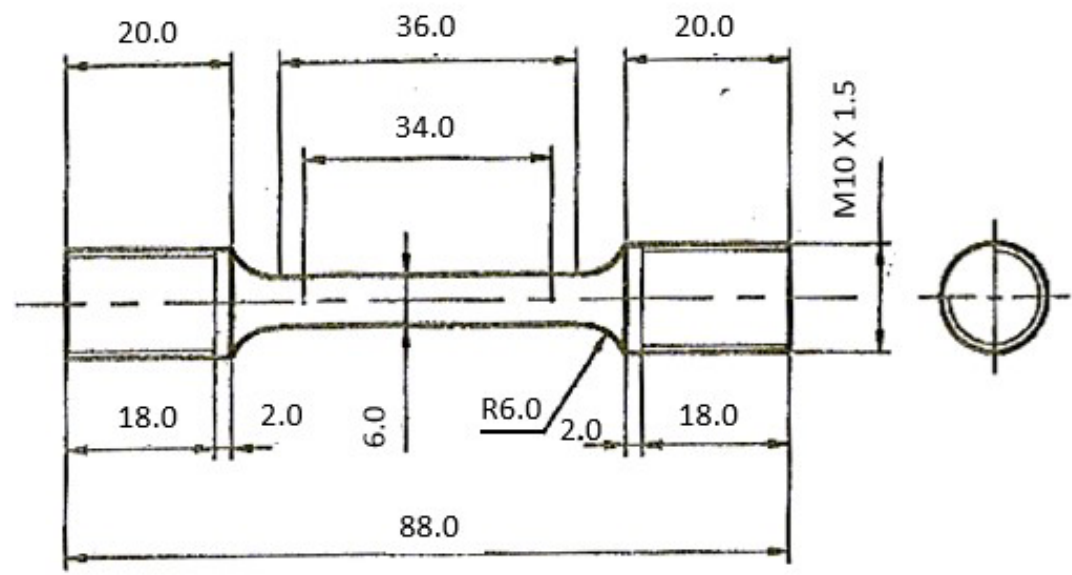

Figure 2. Schematic view of the specimens for hot tensile test ${ }^{16}$. 
Table 1. Hot tensile test data of Inconel 718 superalloy as received.

\begin{tabular}{cccc}
\hline Temperature $\left({ }^{\circ} \mathrm{C}\right)$ & $\sigma_{\mathrm{e}}(\mathrm{MPa})$ & $\sigma_{\text {max }}(\mathrm{MPa})$ & $\mathrm{A}_{\mathrm{p}}(\%)$ \\
\hline 600 & 725 & 1059 & 35.00 \\
\hline 650 & 700 & 974 & 28.37 \\
\hline 700 & 774 & 888 & 11.00 \\
\hline 750 & 755 & 811 & 11.44 \\
\hline 800 & 650 & 664 & 18.20 \\
\hline 850 & 430 & 435 & 33.91 \\
\hline
\end{tabular}

materials ${ }^{6}$. Table 1 presents the values for: yield strength $\left(\sigma_{\mathrm{e}}\right)$, maximum strength $\left(\sigma_{\text {máx }}\right)$ and percent elongation $\left(\mathrm{A}_{\mathrm{p}}\right)$.

The results indicated that decreased yield strength with increased temperature. At 700 and at $750{ }^{\circ} \mathrm{C}$ where the yield strength had the highest values, elongations and the maximum strength were decreasing. This behavior also appears to be associated with the combination of softening caused by rising temperatures and the formation of precipitates in this temperature range.

There is an increase of stress to a maximum value followed softening normally associated with a dynamic recovery or recrystallization depending on the temperature test. The yield strength shows a slight decrease from 600 to $650{ }^{\circ} \mathrm{C}$, with a subsequent increase and reaching a maximum value at $700{ }^{\circ} \mathrm{C}$. From this temperature the yield strength decreases steadily with increasing temperature tests. The expected behavior was the decrease in yield strength with increasing temperature test. The higher value of yield strength at $700^{\circ} \mathrm{C}$ can be attributed probably to the presence of hardening precipitates formed around this temperature. According to Thomas et al. ${ }^{32}$ secondary phases $\gamma$ 'and $\gamma$ " can be found in less extension below $700{ }^{\circ} \mathrm{C}$. These results obtained should be associated with the competition between the softening caused by the increase of test temperature and precipitation hardening compounds.

Caliari et al study the uniaxial hot tensile test of Inconel 718 before and after double aging treatment which the heat treatment of double aging is capable to reorganize the microstructure of the precipitates and produce three times strengthen yield point. The samples as received increased strengthen yield point with increased the temperature $\left(650^{\circ} \mathrm{C}\right.$ and $700{ }^{\circ} \mathrm{C}$ ). Increasing yield strength may be due to the presence of $\gamma^{\prime}$ phase which can be formed via the heating process in hot tensile test.

\subsection{Oxidation study}

Figure 3 shows that there was not a mass gain at $650^{\circ} \mathrm{C}$, while there was a significant mass gain at $675^{\circ} \mathrm{C}$ and a higher mass gain at $800{ }^{\circ} \mathrm{C}$.

Figure 4 presents the $\mathrm{X}$-ray patterns of the formation of some oxides such as $\mathrm{NiO}, \mathrm{Cr}_{2} \mathrm{O}_{3}, \mathrm{Fe}_{2} \mathrm{O}_{3}$ and $\mathrm{NiCr}_{2} \mathrm{O}_{4}$. Besides the formation of oxides, there is also the formation of a new phase called $\delta$ phase.

\subsection{Transmission electronic microscopy}

It is observed in Figures 5, 6 and 7 that the presence of precipitates increased significantly in the samples after creep test. This is due to the material being subjected to a

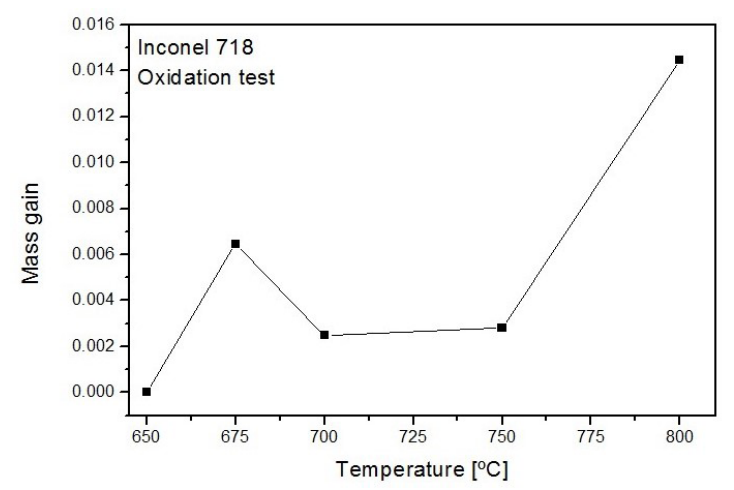

Figure 3. Dependence of mass gain with temperature oxidation test in Inconel 718 alloy.

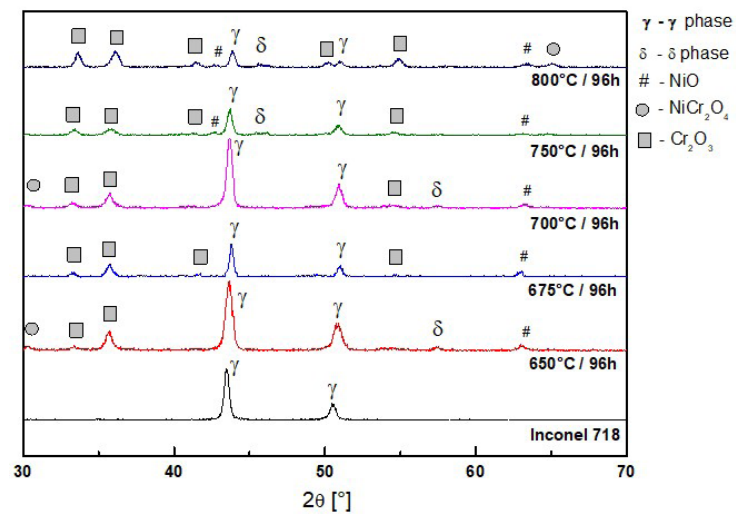

Figure 4. Patterns of X-ray diffraction of Inconel 718 as received and oxidized at different temperatures.

high temperature under stress. Figure $7 \mathrm{~b}$ shows the presence of precipitates of $\delta$ phase.

\subsection{Creep test}

The creep specimen was made according to the specifications shown in Figure 8.

Figure 9 shows all creep curves obtained for the Inconel 718 alloy under conditions of a temperature of 650,675 and $700{ }^{\circ} \mathrm{C}$ and the stress range of 625 to $814 \mathrm{MPa}$.

The curves represent typical creep behavior containing the three creep stages. All experiments were run until specimen failure. The secondary stage was predominant during the creep test, the minimum creep rate shows significant increases with increasing stress. As expected, it can be observed a 


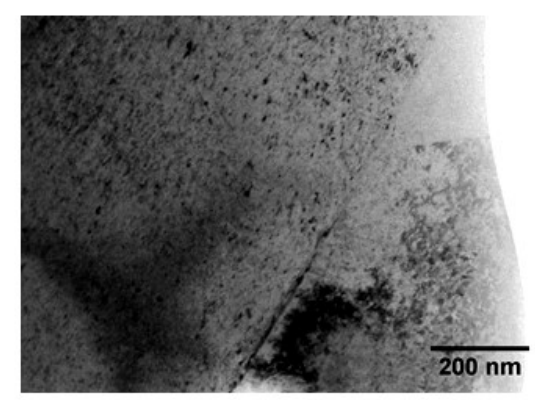

(a) Bright field

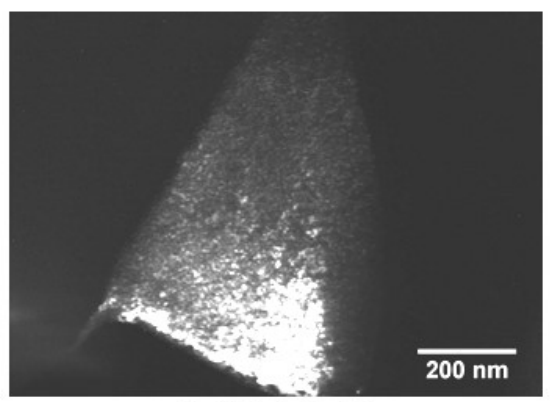

(b) Dark field

Figure 5. TEM images of the Inconel 718 as received.

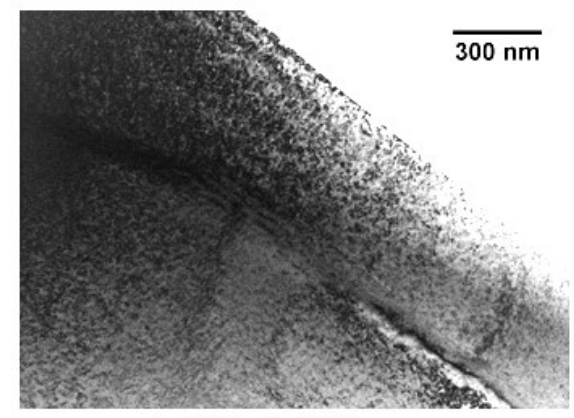

(a) Bright field

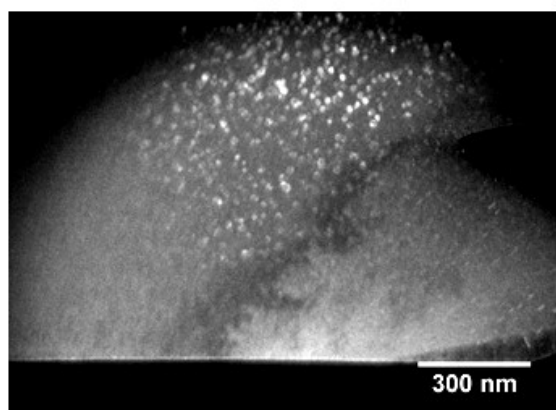

(b) Dark field

Figure 6. TEM images of Inconel 718 crept at $700{ }^{\circ} \mathrm{C}$ and $700 \mathrm{MPa}$.

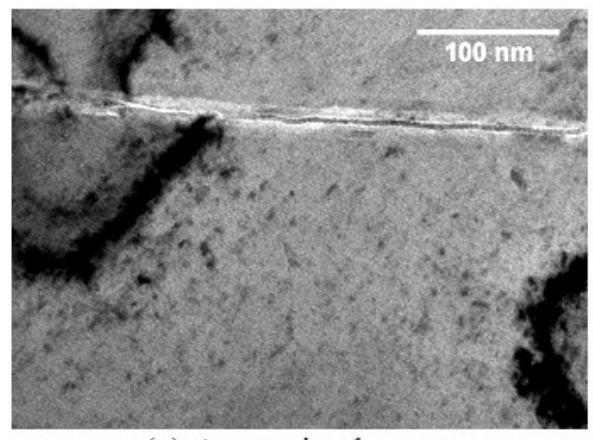

(a) As received.

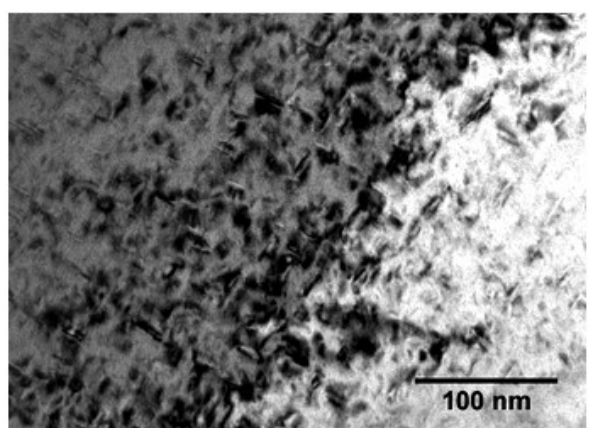

(b) Crept at $700{ }^{\circ} \mathrm{C}$ and $700 \mathrm{MPa}$.

Figure 7. TEM images of Inconel 718.

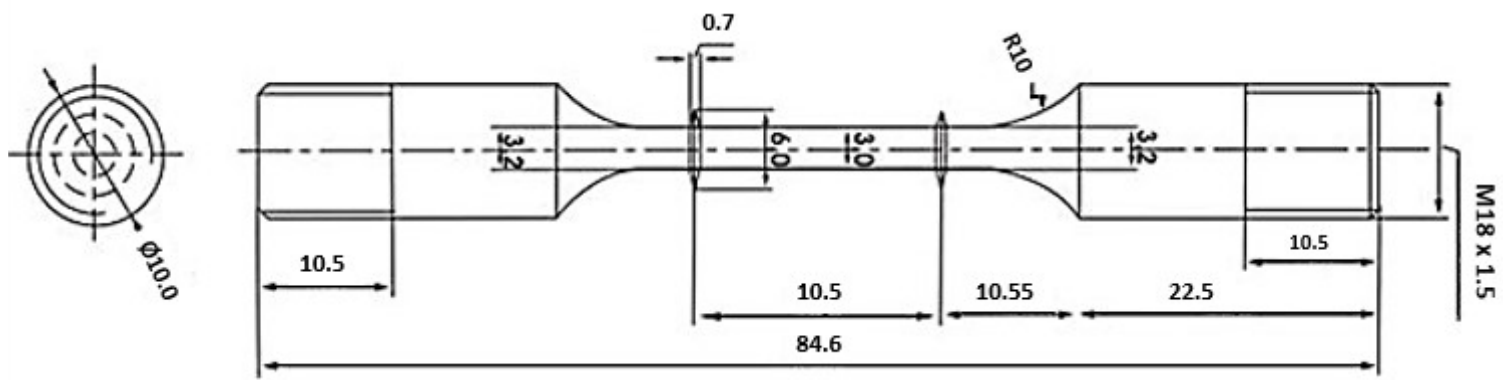

Figure 8. Schematic view of the specimen for creep test ${ }^{17}$. 


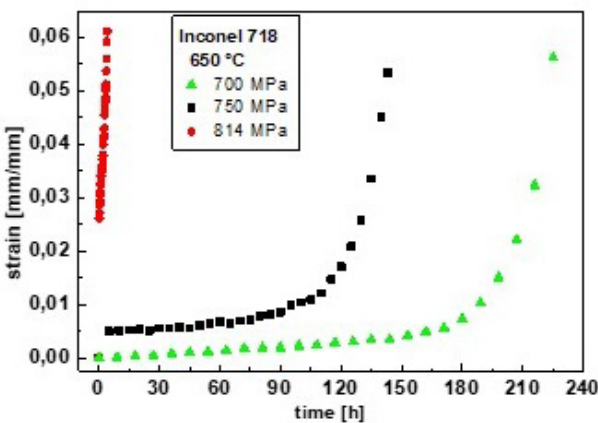

(a) $650^{\circ} \mathrm{C}$

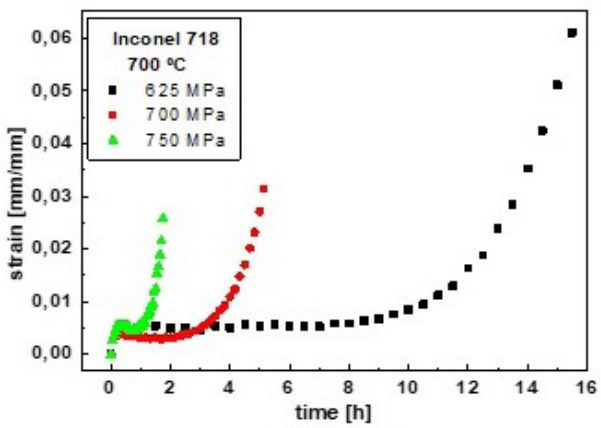

(c) $700{ }^{\circ} \mathrm{C}$

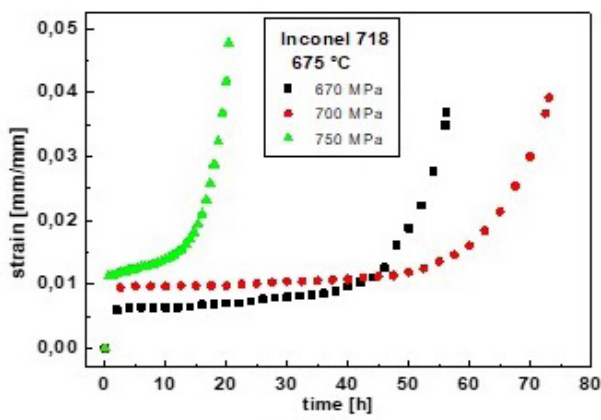

(b) $650^{\circ} \mathrm{C}$

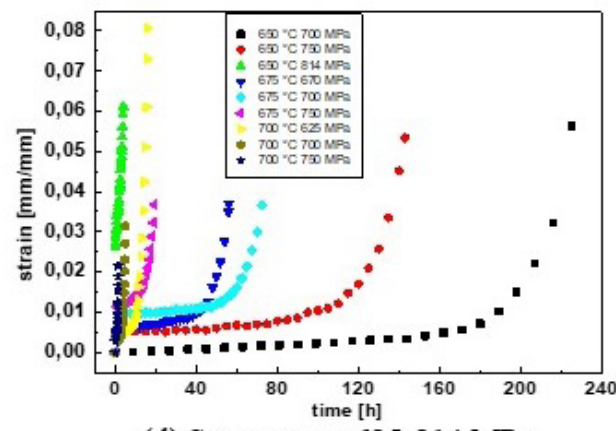

(d) Stress range 625-814 MPa

Figure 9. Creep curves of Inconel 718 superalloy.

Table 2. Creep test parameters.

\begin{tabular}{cccccc}
\hline $\mathrm{T}\left({ }^{\circ} \mathrm{C}\right)$ & $\sigma(\mathrm{MPa})$ & $\mathrm{t}_{\mathrm{p}}(\mathrm{h})$ & $\dot{\varepsilon}_{\mathrm{s}}(1 / \mathrm{h})$ & $\mathrm{t}_{\mathrm{f}}(\mathrm{h})$ & $\varepsilon_{\mathrm{f}}(\mathrm{mm} / \mathrm{mm})$ \\
\hline \multirow{3}{*}{650} & 700 & 9.00 & 0.000024 & 225.00 & 0.0562 \\
\cline { 2 - 6 } & 750 & 6.00 & 0.000041 & 92.70 & 0.0604 \\
\cline { 2 - 6 } & 814 & 0.25 & 0.006160 & 4.00 & 0.0612 \\
\cline { 2 - 6 } 675 & 670 & 4.00 & 0.000080 & 56.15 & 0.0369 \\
\hline & 700 & 2.50 & 0.000040 & 73.07 & 0.0392 \\
\hline \multirow{2}{*}{700} & 750 & 0.67 & 0.000330 & 20.38 & 0.0477 \\
& 625 & 1.50 & 0.000190 & 16.28 & 0.0807 \\
& 700 & 0.33 & 0.000900 & 5.10 & 0.0314 \\
\hline
\end{tabular}

significant increase in the material's creep life with the decreasing stress applied at the test.

Table 2 shows the relation of the main experimental parameters obtained at 650,675 and $700{ }^{\circ} \mathrm{C}$, respectively, from the experimental curve, where in the stress applied is $\sigma ; \dot{\varepsilon}_{\mathrm{s}}$ corresponds to the steady state rate, obtained from the slope of the linear region of the creep curve (secondary stage). The value of $t_{p}$ (primary time) corresponds to the time constant and is obtained at the end of the primary stage and/ or early secondary stage. The value of $t_{f}$ is the fracture final time, $\varepsilon_{\mathrm{f}}$ corresponds to the fracture strain.

The activation energy value $\mathrm{Q}_{\mathrm{c}}=512.97 \mathrm{~kJ} / \mathrm{mol}$ found in this study agrees with the values reported in the literature.
Song et al. ${ }^{33}$ found the value of $\mathrm{Q}_{\mathrm{c}}=595.5 \mathrm{~kJ} / \mathrm{mol}$ for a heat treated superalloy, with chemical composition next to this, creep tested under the conditions of $580 \mathrm{MPa}$ in the range $\mathrm{T}=650$ to $775^{\circ} \mathrm{C}$.

Sugahara et al. ${ }^{29}$ studied the creep test for Inconel 718 alloy at 650,675 and $700{ }^{\circ} \mathrm{C}$ and the range of stress was from 625 to $814 \mathrm{MPa}$ and the higher creep resistance at smaller temperatures and stresses. Analysis of the stress exponent value $(n=36.48)$ and activation energy $\left(Q_{c}=512.97 \mathrm{~kJ} / \mathrm{mol}\right)$ suggests that the creep mechanism at $650{ }^{\circ} \mathrm{C}$ is consistent with the dislocation climb one.

According to Oliveira et al, the results of the creep test with nickel-based superalloy 625 suggested that the 
dominant mechanism is dislocation creep with the values of $\mathrm{n}=11.76$ and $\mathrm{Q}_{\mathrm{c}}=407 \mathrm{~kJ} / \mathrm{mol}$.

Considering creep mechanism at $675^{\circ} \mathrm{C}$ of VAT 32 (superalloys with intermediate nickel content different amounts of carbon, iron, titanium, and niobium) by Gobbi et al. ${ }^{10}$, the stress exponent value is 13.72 and activation energy is $616 \mathrm{~kJ} / \mathrm{mol}$, results were correlated to formation of higher amount of carbides and intermetallic phases caused by higher mass percentage of carbon and different amounts of alloying elements.

It can be seen in Figure 10 the fracture was ductile at $650{ }^{\circ} \mathrm{C}$. The fracture images showed the presence of dimples that are a typical coalescence of microvoids. In Figure 11 it can be observed with the small increase of temperature to $675{ }^{\circ} \mathrm{C}$ there was a change in the type of fracture to intergranular and in Figure 12 presents a ductile fracture at $700{ }^{\circ} \mathrm{C}$ with the presence of dimples, a typical coalescence of microvoids.

Kuo et al. ${ }^{21}$ reported the ductile type (transgranular) fracture mostly and a small portion of intergranular fracture in superalloy Inconel 718 heat treated to precipitate $\gamma^{\prime}$ and $\gamma$ " phases.

Wu et al. ${ }^{34}$ investigated the microstructure evolution and creep behavior after high-temperature annealing treatments of $\mathrm{Ni}_{3} \mathrm{Al}$-based superalloy with multiphase. The high-temperature annealing treatments prolonged the creep rupture life and the

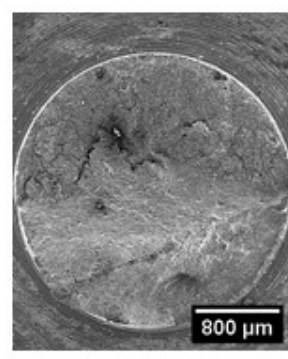

(a) general view

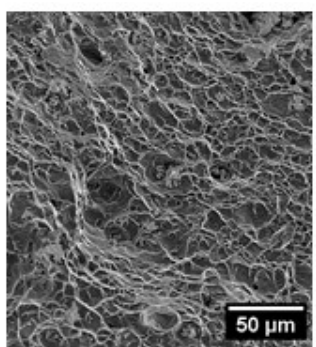

(b) lateral view

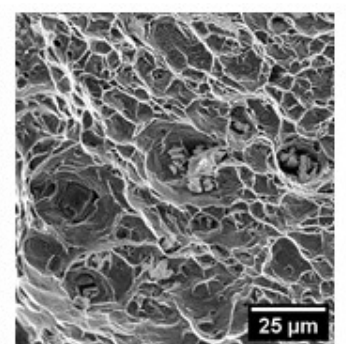

(c) higher magnification

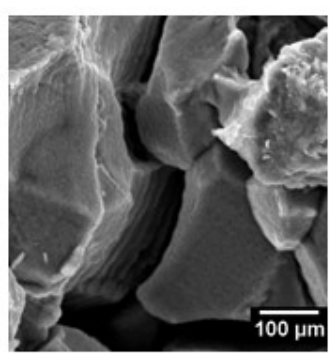

(d) center view

Figure 10. Fracture surface of Inconel 718 after creep test at $650{ }^{\circ} \mathrm{C}$ and $700 \mathrm{MPa}$.

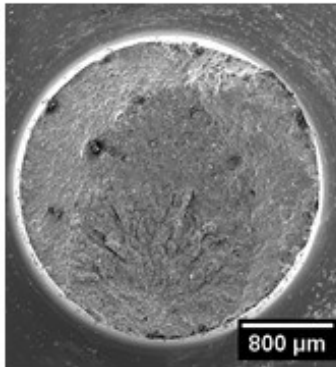

(a) general view

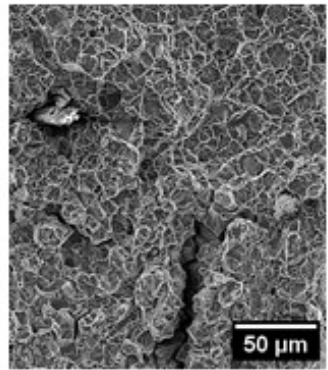

(b) lateral view

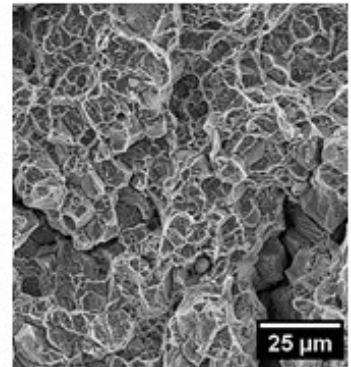

(c) higher magnification

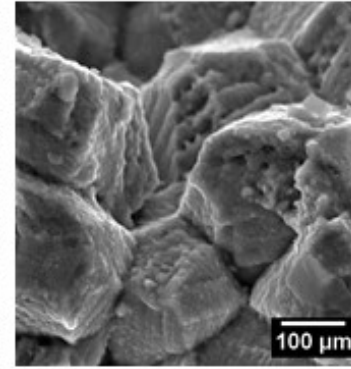

(d) center view

Figure 11. Fracture surface of Inconel 718 after creep test at $675^{\circ} \mathrm{C}$ and $700 \mathrm{MPa}$.

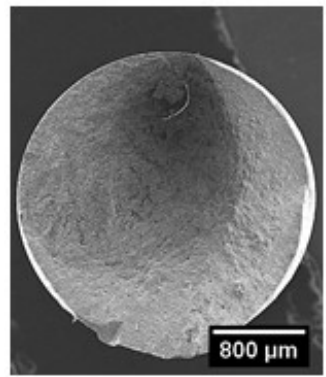

(a) general view

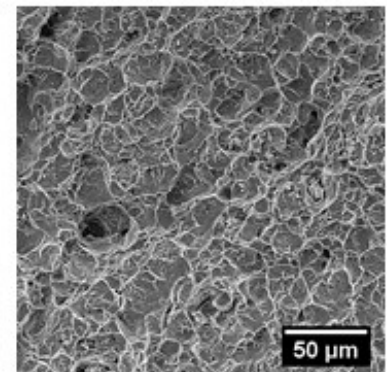

(b) lateral view

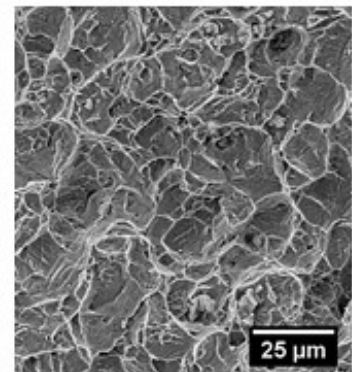

(c) higher magnification

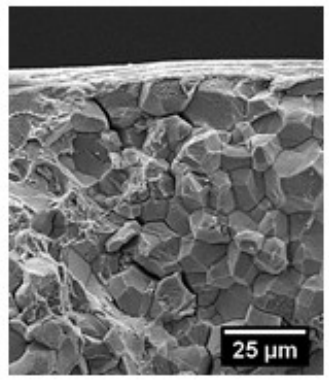

(d) center view

Figure 12. Fracture surface of Inconel 718 after creep test at $700{ }^{\circ} \mathrm{C}$ and $700 \mathrm{MPa}$. 
minimum steady-state creep rate was obtained on account of the largest $\gamma^{\prime}$ phase after annealing at $1280^{\circ} \mathrm{C}$. In addition to cracks are initiated at the grain boundaries where carbides existed and propagated near the boundaries between interdendritic $\beta$ phase and $\gamma^{\prime}$ envelope during creep process.
Figure 13 presents the images of scanning electron microscopy after creep test, which show increased test temperature for the same stress condition $(700 \mathrm{MPa})$ increased the appearance of precipitates, as can be confirmed by EDS analysis in Figure 14.

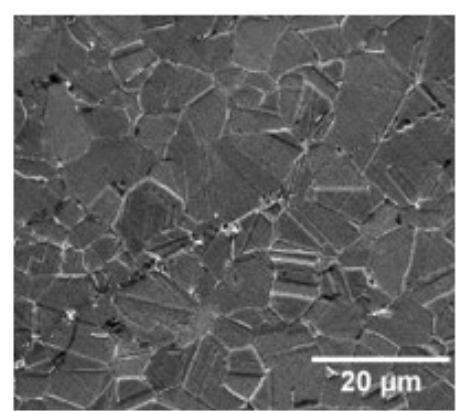

(a) $650^{\circ} \mathrm{C}$

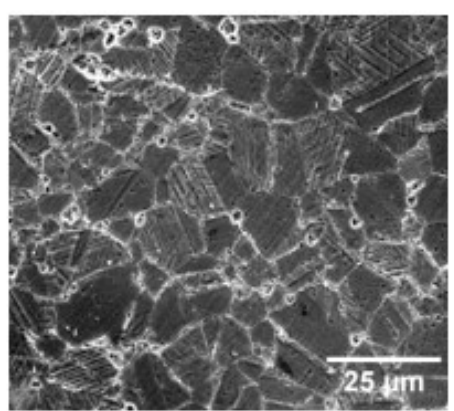

(b) $675^{\circ} \mathrm{C}$

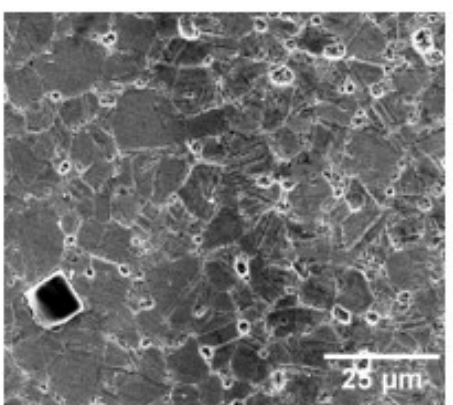

(c) $700^{\circ} \mathrm{C}$

Figure 13. Cross section microstructure of Inconel 718 after creep test.

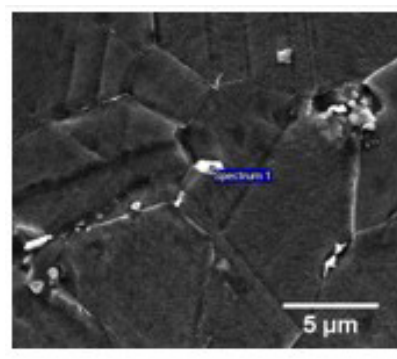

a) $650^{\circ} \mathrm{C}$
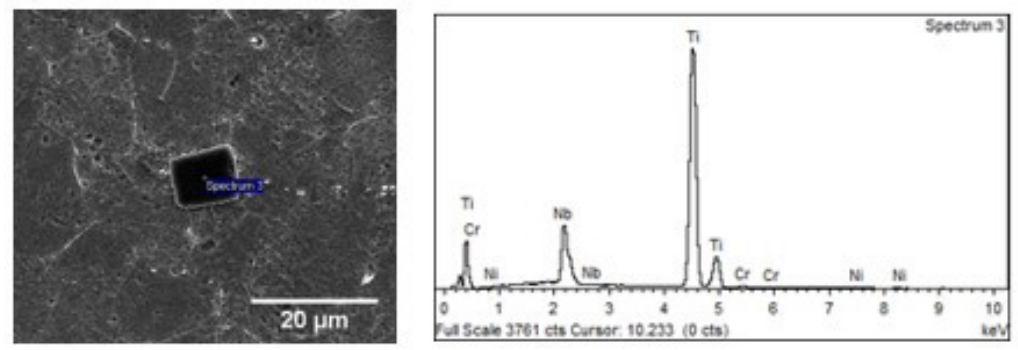

b) $675^{\circ} \mathrm{C}$
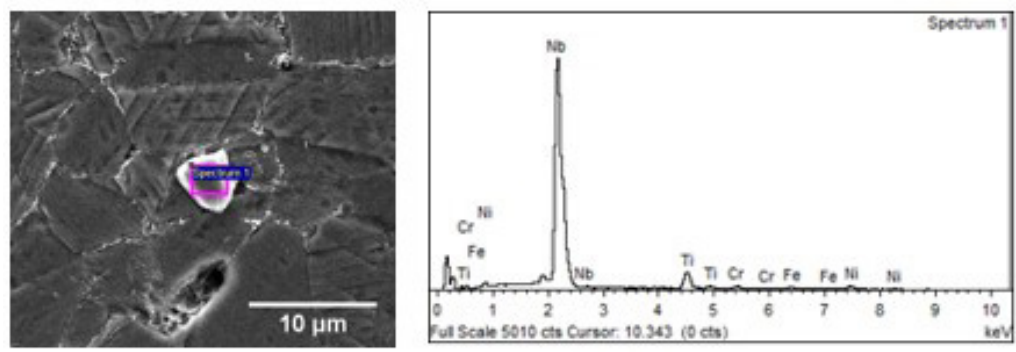

c) $700^{\circ} \mathrm{C}$

Figure 14. EDS of Inconel 718 after creep test at $700 \mathrm{MPa}$. 


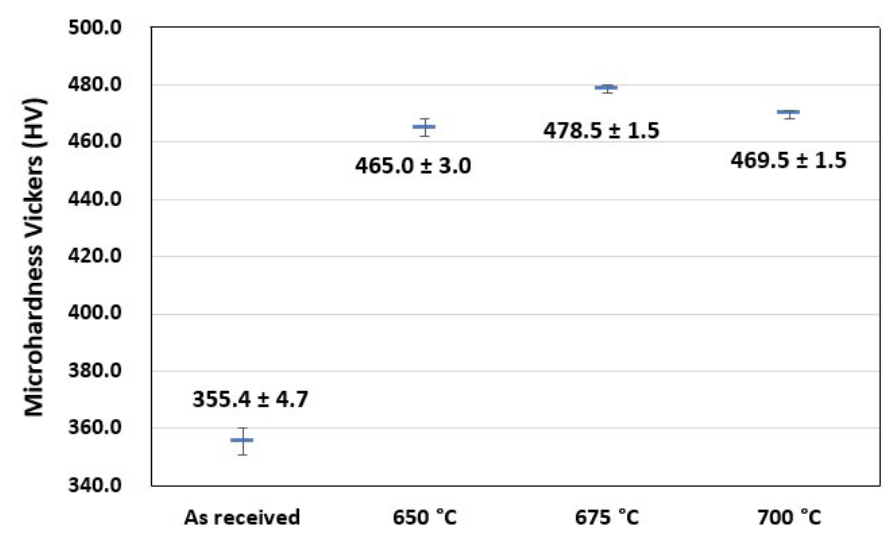

Figure 15. Vickers microhardness values.

\subsection{Hardness test}

The microhardness measures are presented in Figure 15. The microhardness value increased with the temperature, and the highest hardness value appeared at $675^{\circ} \mathrm{C}$. It could be concluded that there is an aging (DSA) Inconel 718 superalloy during the creep test confirmed by microstructural changes and hardness increase.

The microhardness result was related to the consumption of elements, especially niobium, that forms $\gamma^{\prime}$ and $\gamma$ ', responsible for the precipitation hardening that occurs at $600{ }^{\circ} \mathrm{C}$. Such precipitation hardening was confirmed by the increase in yield stress and SEM precipitate observations. Simultaneously, an abnormal reduction in ductility occurred. DSA and $\gamma$ ' and $\gamma$ " precipitations were responsible for the high strength at elevated temperature of this alloy but have no role in the sharp decrease in its ductility.

\section{Conclusions}

Inconel 718 hardness measures were close to that provided by the manufacturer (without heat treatment), and after creep tests, the value of microhardness measures increased with the temperature, so that the highest hardness value appeared at $675^{\circ} \mathrm{C}$.

The increased temperature showed decreased yield strength of the Inconel 718 superalloy. But there were higher values of yield strength at $700^{\circ} \mathrm{C}$, this anomalous behavior could be attributed probably to the presence of hardening precipitates formed at temperatures around $700{ }^{\circ} \mathrm{C}$.

The Inconel 718 superalloy showed a typical creep behavior with the presence of the three creep stages. The secondary stage was predominant during the test, the minimum creep rate increased significantly with increasing stress applied.

The analysis of the stress exponent value $(n=36.48)$ and the activation energy $\left(Q_{c}=512.97 \mathrm{KJ} / \mathrm{mol}\right)$ suggested that the creep mechanism at $650{ }^{\circ} \mathrm{C}$ was the climb dislocation mechanism.

In the oxidation tests could be observed the formation of various oxides, which generally served as a protective layer for the alloy, therefore it was formed as thin films on the surface preventing the loss of mass.

In the TEM images could be observed the increased amount of precipitates after creep test. This was due to the material being subjected to stress and temperature for a long time.
It could be observed in this work that the Inconel 718 superalloy was very resistant at temperatures up to approximately $650^{\circ} \mathrm{C}$ and to worked above this temperature, it was necessary to perform thermal aging treatments for this superalloy to become more resistant with the new phases precipitation.

\section{Acknowledgment}

The authors wish to acknowledge the financial support from FAPESP. This study was financed in part by the Coordenação de Aperfeiçoamento de Pessoal de Nível Superior - Brasil (CAPES) - Finance Code 001.

\section{References}

1. Sims CT, Stoloff NS, Hagel WC. Superalloys II high temperature materials for aerospace and industrial power. New York: J. Willey; 1987. $640 \mathrm{p}$.

2. Collier JP, Wong SH, Tien JK, Phillips JC, Tein JK. The effect of varying $\mathrm{AI}, \mathrm{Ti}$, and $\mathrm{Nb}$ content on the phase stability of INCONEL 718. Metall Trans A. 1988;19(7):1657-66.

3. Hughes J, England R, Muralidharan G, Maziasz P, Shyam A, Pierce D, et al. High temperature materials for heavy duty diesel engines: historical and future trends. Prog Mater Sci. 2019;103:109-79. http://dx.doi.org/10.1016/j.pmatsci.2018.10.004.

4. Sonar T, Balasubramanian V, Malarvizhi S, Venkateswaran T, Sivakumar D. An overview on welding of Inconel 718 alloy effect of welding processes on microstructural evolution and mechanical properties of joints. Mater Charact. 2021;174:110997. http://dx.doi.org/10.1016/j.matchar.2021.110997.

5. De Oliveira MM, Couto AA, Almeida GFC, Reis DAP, De Lima NB, Baldan R. Mechanical behavior of inconel 625 at elevated temperatures. Metals (Basel). 2019;9(3)

6. Caliari FR, Candioto KCG, Reis DAP, Couto AA, De Moura C No, Nunes CA. Study of the mechanical behavior of an inconel 718 aged superalloy submitted to hot tensile tests. SAE Tech Pap. 2011:1-9.

7. Caliari FR, Candioto KCG, Couto AA, Nunes CÂ, Reis DAP. Effect of double aging heat treatment on the short-term creep behavior of the inconel 718. J Mater Eng Perform. 2016;25(6):2307-17.

8. Martinolli K, Sugahara T, Reis DAP, de Moura C No, Hirschmann AC, Couto AAAA. Evaluation of Inconel 718 creep behavior. Defect Diffus Forum. 2012;326-328:525-9.

9. Han L, Li P, Yu S, Chen C, Fei C, Lu C. Creep/fatigue accelerated failure of Ni-based superalloy turbine blade: microscopic 
characteristics and void migration mechanism. Int J Fatigue. 2021;154:106558. http://dx.doi.org/10.1016/j.ijfatigue.2021.106558.

10. Gobbi VJ, Gobbi SJ, Reis DAP, Ferreira JLA, Araújo JA, Da Silva CRM. Creep behaviour and microstructural characterization of VAT 36 and VAT 32 superalloys. Metals (Basel). 2018;8(11):877.

11. Galizoni BB, Couto AA, Reis DAP. Heat treatments effects on nickel-based superalloy inconel 713C. Metals (Basel). 2019;9(1)

12. Oliveira MM, Couto AA, Baldan R, Reis DAP, Vatavuk J, Vendramim JC, et al. High temperature mechanical behavior of plasma-nitrided Inconel 625 superalloy. In: Öchsner A, da Silva LFM, Altenbach H. Advanced structured materials [Internet]. Cham: Springer; 2017. p. 197-214 [cited 2021 June 11]. Available from: http://link.springer.com/10.1007/978-981-10-1602-8

13. He DG, Lin YC, Jiang XY, Yin LX, Wang LH, Wu Q. Dissolution mechanisms and kinetics of $\delta$ phase in an aged Ni-based superalloy in hot deformation process. Mater Des. 2018;156:262-71. http:// dx.doi.org/10.1016/j.matdes.2018.06.058.

14. Feng Y, Pan Z, Liang SY. Temperature prediction in Inconel 718 milling with microstructure evolution. Int J Adv Manuf Technol. 2018;95(9-12):4607-21.

15. Candioto KCG, Caliari FR, Reis DAP, Couto AA, Nunes CA. Characterization of the superalloy Inconel 718 after double aging heat treatment. In: Öchsner A, Altenbach H, editors. Mechanical and materials engineering of modern structure and component design. advanced structured materials. Vol. 70. Cham: Springer. p. 293-300. https://doi.org/10.1007/978-3-319-19443-1_24.

16. Wu Y, Liu Y, Li C, Xia X, Wu J, Li H. Coarsening behavior of $\gamma^{\prime}$ precipitates in the $\gamma^{\prime}+\gamma$ area of a Ni3Al-based alloy. J Alloys Compd. 2019;771:526-33.

17. Qin H, Bi Z, Yu H, Feng G, Du J, Zhang J. Influence of stress on $\gamma^{\prime \prime}$ precipitation behavior in Inconel 718 during aging. $\mathrm{J}$ Alloys Compd. 2018;740:997-1006.

18. Yadav PC, Sahu S, Subramaniam A, Shekhar S. Effect of heat-treatment on microstructural evolution and mechanical behaviour of severely deformed Inconel 718. Mater Sci Eng A. 2018;715:295-306. http://dx.doi.org/10.1016/j.msea.2018.01.007.

19. Cahit A, Mert K, Demirel B, Turk A, Karaoglanli AC, Doleker $\mathrm{KM}$, et al. Effect of shot peening on the oxidation behavior of thermal barrier coatings. Appl Surf Sci. 2015;354:314-22. http://dx.doi.org/10.1016/j.apsusc.2015.06.113.

20. Valerio P, Gao M, Wei RP. Environmental enhancement of creep crack growth in inconel 718 by oxygen and water vapor. Scr Metall Mater. 1994;30(10):1269-74.

21. Kuo CM, Yang YT, Bor HY, Wei CN, Tai CC. Aging effects on the microstructure and creep behavior of Inconel 718 superalloy. Mater Sci Eng A. 2009;510-511:289-94.

22. Ma W, Xie Y, Chen C, Fukanuma H, Wang J, Ren Z, et al. Microstructural and mechanical properties of high-performance
Inconel 718 alloy by cold spraying. J Alloys Compd. 2019;792:45667. http://dx.doi.org/10.1016/j.jallcom.2019.04.045.

23. Ardi DT, Guowei L, Maharjan N, Mutiargo B, Leng SH, Srinivasan R. Effects of post-processing route on fatigue performance of laser powder bed fusion Inconel 718. Addit Manuf. 2020;36:101442. http://dx.doi.org/10.1016/j.addma.2020.101442.

24. Liu WC, Yao M, Chen ZL, Wang SG. Niobium segregation in Inconel 718. J Mater Sci. 1999;34(11):2583-6.

25. Sugahara T, Martins GV, Montoro FE, Merij A No, Massi M, da Silva Sobrinho AS, et al. Creep behavior evaluation and characterization of $\mathrm{SiC}$ film with $\mathrm{Cr}$ interlayer deposited by HiPIMS in Ti-6Al-4V alloy. Surf Coat Tech. 2017;309:410-6. http://dx.doi.org/10.1016/j.surfcoat.2016.11.091.

26. dos Reis AG, Reis DAP, de Moura Neto C, Barboza MJR, Oñoro J. Creep behavior and surface characterization of a laser surface nitrided Ti-6Al-4V alloy. Mater Sci Eng A. 2013;577:48-53. http://dx.doi.org/10.1016/j.msea.2013.04.042.

27. de Freitas FE, Briguente FP, Reis AG, Vasconcelos G, Reis DAP. Investigation on the microstructure and creep behavior of laser remelted thermal barrier coating. Surf Coat Tech. 2019;369:25764. http://dx.doi.org/10.1016/j.surfcoat.2019.04.068.

28. Xu Z, Cao L, Zhu Q, Guo C, Li X, Hu X, et al. Creep property of Inconel 718 superalloy produced by selective laser melting compared to forging. Mater Sci Eng A. 2020;794:139947. http://dx.doi.org/10.1016/j.msea.2020.139947.

29. Sugahara T, Martinolli K, Reis DAP, Moura C No, Couto AA, Piorino F No, et al. Creep behavior of the inconel 718 superalloy. Defect Diffus Forum. 2012;326-328:509-14.

30. ASTM International. ASTM E8-E8M-16ae1: Standard Test Methods for Tension Testing of Metallic Materials [Internet]. West Conshohocken, PA: ASTM International; 2016 [cited 2021 June 11]. Available from: www.astm.org

31. ASTM International. ASTM E139-06: Standard Test Methods for Conducting Creep, Creep-Rupture, and Stress-Rupture Tests of Metallic Materials [Internet]. West Conshohocken, PA: ASTM International; 2006 [cited 2021 June 11]. Available from: www.astm.org

32. Thomas A, El-Wahabi M, Cabrera JM, Prado JM. High temperature deformation of Inconel 718. J Mater Process Technol. 2006;177(1-3):469-72.

33. Song HW, Guo SR, Lu DZ, Xu Y, Wang YL, Lin DL, et al. Compensation effect in creep of conventional polycrystalline alloy 718. Scr Mater. 2000;42(9):917-22.

34. Wu J, Li C, Liu Y, Wu Y, Guo Q, Li H, et al. Effect of annealing treatment on microstructure evolution and creep behavior of a multiphase Ni3Al-based superalloy. Mater Sci Eng A. 2019;743:623-35. http://dx.doi.org/10.1016/j. msea.2018.11.126. 